\title{
Sediment flushing in Mystic Cave, West Virginia, USA, in response to the 1985 Potomac Valley flood
}

\author{
James J. Van Gundy ${ }^{1}$ and William B. White ${ }^{2}$
}

\begin{abstract}
:
Van Gundy J.J. and White W.B. 2009. Sediment flushing in Mystic Cave, West Virginia, USA, in response to the 1985 Potomac Valley flood. International Journal of Speleology, 38 (2), 103-109. Bologna (Italy). ISSN 0392-6672.

The great November 5, 1985 Potomac Valley flood was responsible for the release of $1800 \mathrm{~m}^{3}$ of alluvial and colluvial sediment from the walls of the entrance doline of Mystic Cave. Flood waters were sufficiently powerful to flush the entire mass of sediment not only into the cave but through the cave. Remnants of the sediment mass in the form of sand bars and a few cobbles wedged in speleothems were the only evidence in the cave that the huge mass of sediment had moved through. The sediment moved as a suspended mass in water moving at peak velocities of many meters per second. Present day cave sediments must be interpreted with the understanding that entire sediment fillings can be transported or rearranged by single extreme events.
\end{abstract}

Keywords: Mystic Cave, Floods, Clastic Sediments, West Virginia

Received 4 November 2008; Revised 21 January 2009; Accepted 10 February 2009

\section{INTRODUCTION}

Many caves contain deposits of clastic sediments ranging in size from clays and silts to gravels, cobbles and occasionally boulders (Bosch and White, 2004). An extreme example was the $1-2$ meter sandstone boulders apparently flushed out of a sump in Aqua Cave, Highland County, Virginia, USA (Palmer \& Palmer, 2005). These deposits are usually composed of quartz sand and sandstone as well as other noncarbonate rocks clearly derived from locations distant from the caves in which they are found. It is generally agreed that clastic sediment transport is an episodic event with distinct thresholds for the movement of particles in a given size range (Herman et al., 2008). Fine-grained sediments can be transported either as bedload or in suspension by moderate storm flows (Dogwiler \& Wicks, 2004). Transport of cobbles and boulders requires extreme storms and such conditions occur only rarely. One documented example of the effects of extreme storms was the sediment scouring of Cave Springs Cave, near Lexington, Virginia, by Hurricane Camille in 1969 (Doehring \& Vierbuchen, 1971). In this example, the storm flow transported sediment in the sand to cobble size range and scoured the cave walls of existing sediment coatings.

1. Department of Environmental Science, Davis and Elkins College, Elkins, WV, USA

2. Materials Research Institute and Department of Geosciences, The Pennsylvania State University, University Park, PA 16802, USA, E-mail: wbw2@psu.edu
Karst springs often become turbid following storms. Collection and measurement of the transported particles reveals particle sizes in the clay to fine silt size range (Atteia \& Kozel, 1997; Mahler \& Lynch, 1999; Drysdale et al., 2001; Massei et al., 2003; Herman et al., 2007). It is apparent that moderate discharge, high frequency, storms generally do not provide sufficient energy to move the coarsegrained sediment. The effects of high discharge, low frequency storms are rarely observed. Measurement is difficult and direct observation would be extremely hazardous.

An opportunity for observation was provided when an extreme storm in the Potomac River drainage in West Virginia, USA, flushed a measurable volume of sediment through a cave system. The present paper describes the event and its aftermath. It was a rare instance in which reasonable estimates of both hydraulic behavior and sediment loading can be inferred for an extreme storm event in a welldefined small karst drainage system. It is an even more interesting example because a large volume of sediment was flushed entirely through the system, leaving only a few traces of its passage.

\section{GEOLOGIC SETTING}

The study site is in the Appalachian Mountains of Pendleton County, West Virginia, in the Potomac River drainage (Fig. 1). The site is on the boundary between the Valley and Ridge Province to the east with strongly folded and faulted older Paleozoic rocks and 


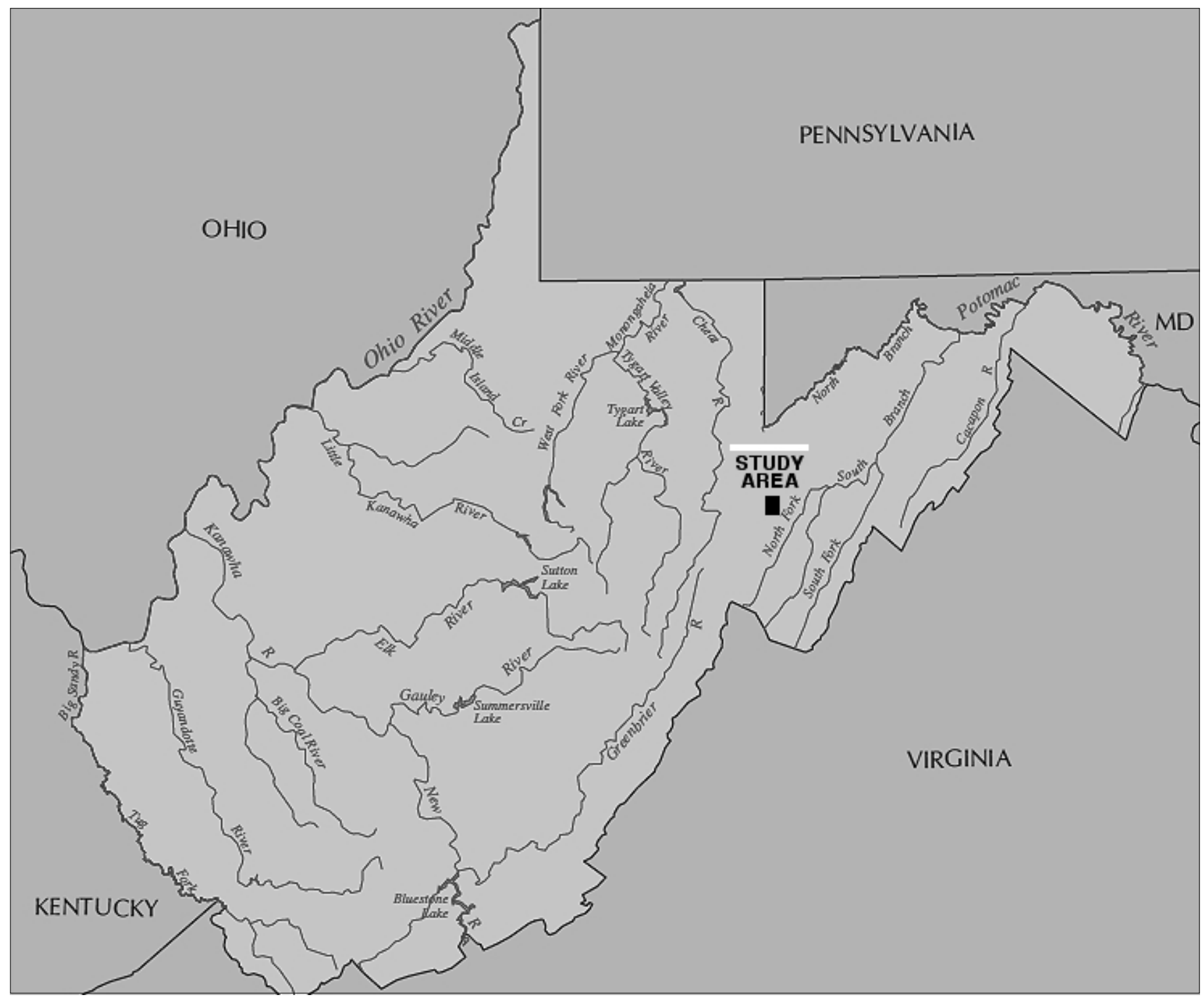

Fig. 1. Drainage map for West Virginia showing location of study area. Map adapted from the U.S. Geological Survey National Atlas of the United States of America.

the Allegheny Plateau Province to the west with less deformed younger Paleozoic rocks. The two provinces are separated by the Allegheny Front, a 500 m-high escarpment. Mystic Cave is formed in Timber Ridge, a segment of the Allegheny Front, separated from the main escarpment by the incised valley of Brushy Run. Brushy Run is a strike-oriented stream flowing northeast as a tributary of Seneca Creek which in turn cuts across strike to join the North Fork of the South Branch of the Potomac River. The site is in the headwaters of the Potomac Drainage. Spruce Knob, the highest point of West Virginia, at an elevation of $1482 \mathrm{~m}$ and a major drainage divide, lies $14 \mathrm{~km}$ to the southwest.

Mystic Cave is a well-known cave (Davies, 1958; Dasher, 2001) located approximately $3 \mathrm{~km}$. west of the village of Seneca Rocks, West Virginia, at an elevation of $685 \mathrm{~m}$ (U.S. Geological Survey Onego 7.5 minute quadrangle). The cave has three entrances, the largest of which is the North Entrance located in a $1 \mathrm{~km}$ long compound doline containing a small permanent stream that sinks at the cave entrance. About $1 \mathrm{~km}$ to the south, a second entrance near the upstream end of the cave also receives a small stream. A third (West) entrance is located at the extreme downstream end of the cave and consists of a tight opening that can only be negotiated with difficulty (Fig. 2).

The cave stream reaches the surface as a large spring about $60 \mathrm{~m}$ distant from the West Entrance, and $30 \mathrm{~m}$ below it. In total, the cave contains about 2,500 $\mathrm{m}$ of passages (Dasher, 2001). The streamways in Mystic Cave have moderate to high gradients. The tributary stream from the South Entrance falls $15 \mathrm{~m}$ over a linear course of about $735 \mathrm{~m}$ for a gradient of $20 \mathrm{~m} / \mathrm{km}$. Downstream from the North Entrance the gradient is much steeper with several waterfalls. The fall is $50 \mathrm{~m}$ to the passage leading to the West Entrance and another $30 \mathrm{~m}$ to the spring over a total length of $588 \mathrm{~m}$ giving a gradient of $137 \mathrm{~m} / \mathrm{km}$.

The apparent watershed area for Mystic cave as determined from the topographic map is approximately 180 ha (Fig. 3). Given the nature of karst drainages, this must be considered a minimum figure, but the true figure is probably not much larger because Mystic Cave underlies the western margin of its surface drainage basin and Blowhole, another sizable stream 


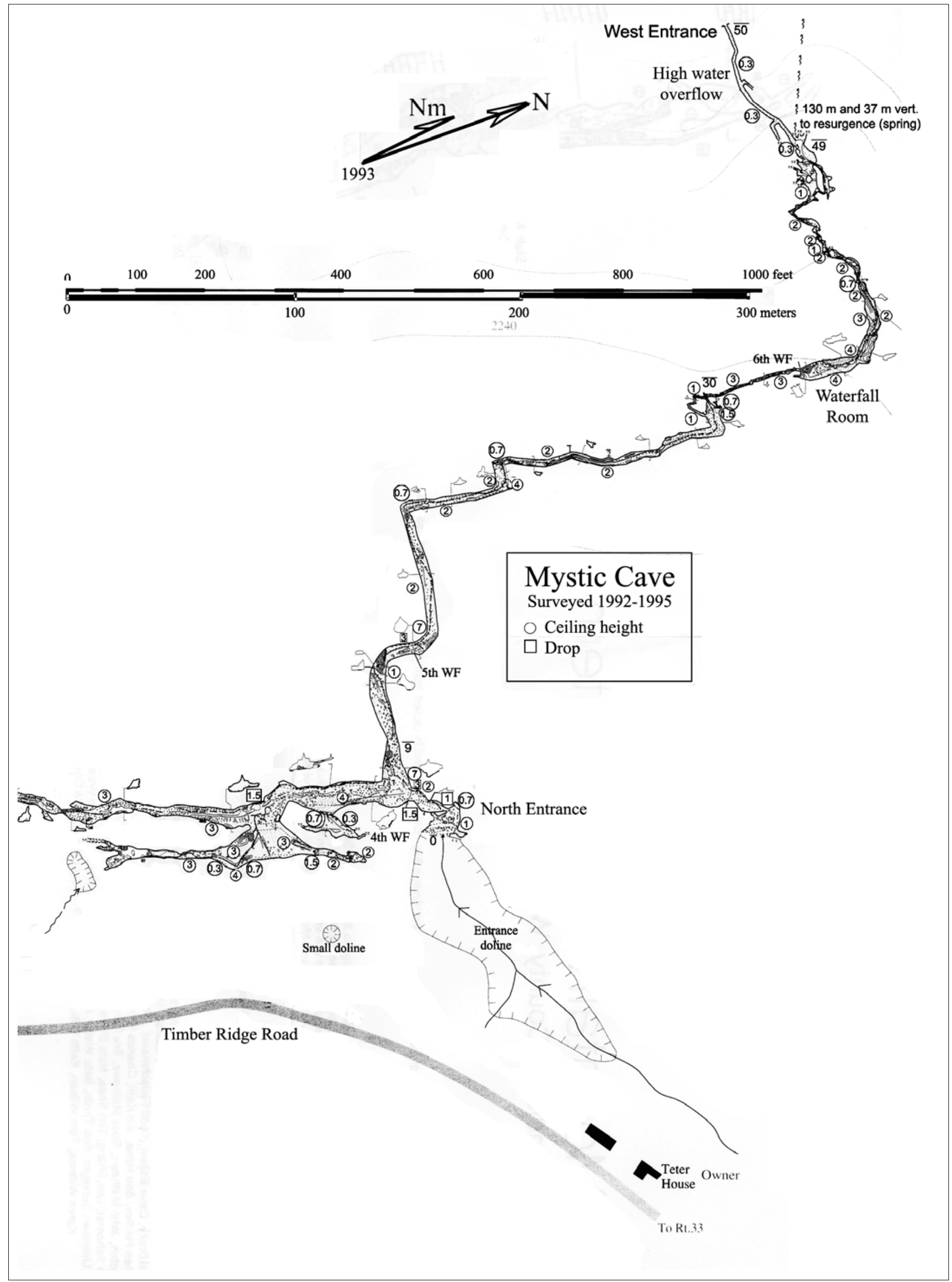

Fig. 2. Map of the downstream segment of Mystic Cave between the North Entrance and the West Entrance. The cave also extends $735 \mathrm{~m}$ to the south. The full detailed map of the cave from which this segment was extracted was prepared by Bob Gulden in 2001 and was published by Dasher (2001). 


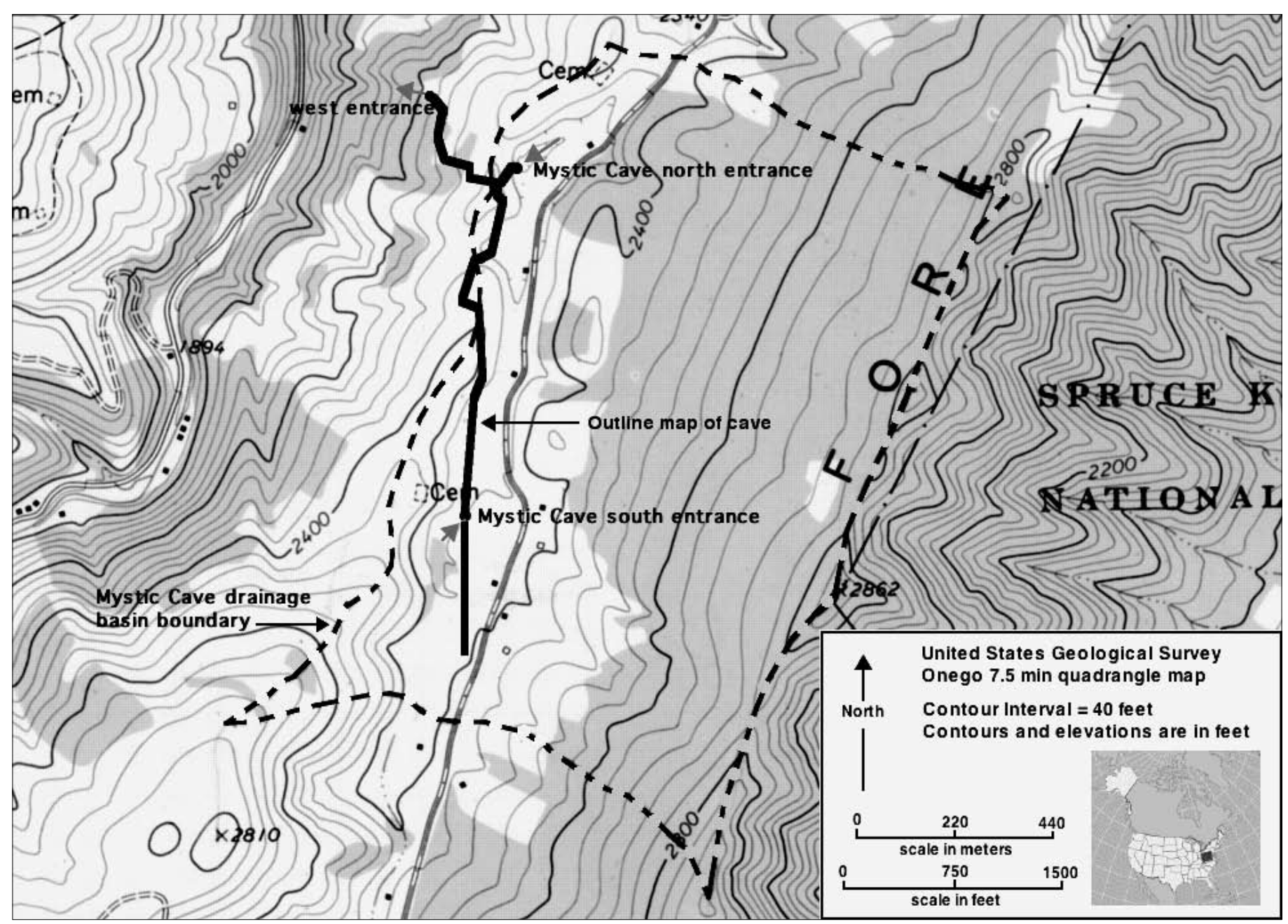

Fig. 3. Segment of U.S. Geological Survey Onego 7.5 minute quadrangle showing the drainage basin boundaries for Mystic Cave (dashed lines). This catchment includes water draining to both the South Entrance and North Entrance streams. The cave is shown as the heavy dark line.

cave system, lies immediately to its west.

Mystic Cave is formed in the Mississippian Greenbrier Limestone. The Greenbrier is a major cave-former in West Virginia but the formation thins from south to north along the main karst belt in eastern West Virginia. Near Mystic Cave the thickness is about 120 $\mathrm{m}$ (Tilton et al., 1927).

\section{THE NOVEMBER, 1985, POTOMAC VALLEY FLOOD}

In early November of 1985, heavy rains totaling nearly $45 \mathrm{~cm}$ fell over a 3 day period and produced floods of record on many streams in western Virginia and eastern West Virginia. This flooding caused 16 deaths and property losses in the hundreds of millions of dollars in the narrow valleys of West Virginia's rural Pendleton County. Not surprisingly, many of the area's numerous caves experienced high water and unusually heavy sediment loading during this period. According to Clark et al. (1987), October was an abnormally wet month in northcentral West Virginia with more than twice normal rainfall. Soils were thus near saturation when the early November storm arrived. The storm was the result of a convergence of several moist air masses, none of which individually would have produced such a cataclysmic event. Teets \& Young (1985) give an account of the human impacts of the storm.
The study area was in the zone of highest rainfall from the storm. Officially, $26.7 \mathrm{~cm}$ of rain was recorded at Seneca Rocks in the valley of the North Fork (US Weather Bureau from the US Forest Service gage at the Seneca Rocks Visitor Center) on November 5 th, the day of heaviest rainfall during the period of interest. Private rain gauges located closer to Mystic Cave and at about the same elevation recorded $43 \mathrm{~cm}$ of rainfall during the same period (Ms. Priscilla Teter, cave owner, private communication). A technical account of the storm (Clark et al., 1987) claims that the floods brought on by the storm were in excess of a 100-year return period and in excess of a 500-year return period near the study area.

\section{THE SEDIMENT FLUSH}

Sediment injection during the flood came from different locations within the closed depression at the North Entrance (Fig. 4). Three large sections of waterlogged soils on the relatively steep walls of the doline slumped into the rain-swollen stream and sent significant volumes of mostly silt to sand sized sediment into the cave (Fig. 5). At the same time, heavy overland flow across a cornfield on the southwestern edge of the doline caused water to cascade over the lip of the inner portion of the depression and rapidly erode a $24 \mathrm{~m}$ by $18 \mathrm{~m}$ bowl-shaped canyon that was nearly $7 \mathrm{~m}$ deep at its lower end (Figs. 6, 7). The material 


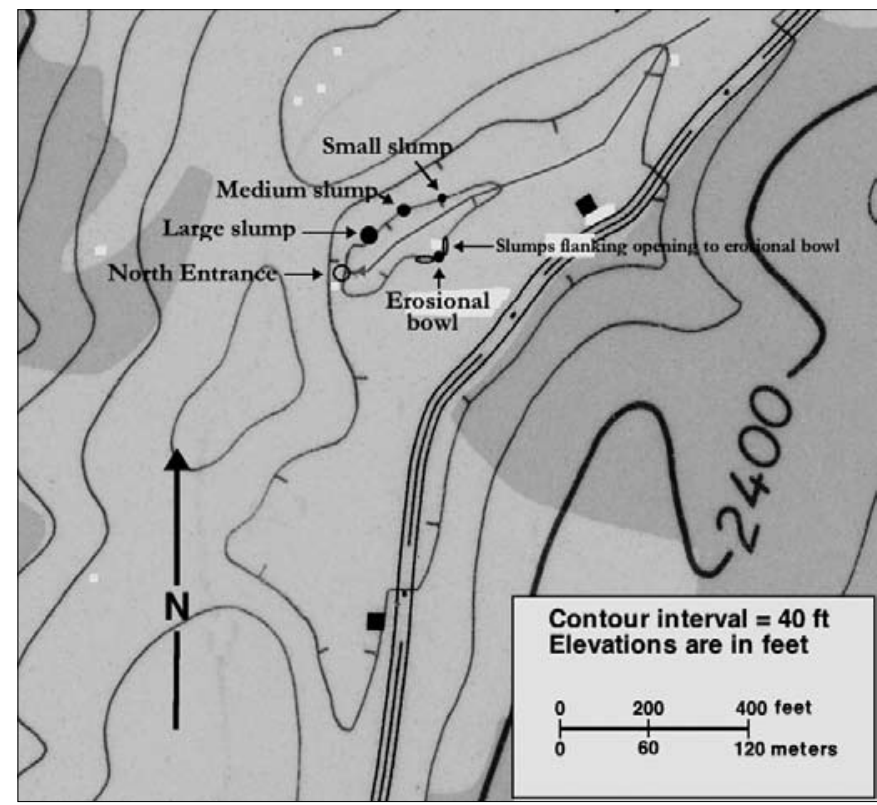

Fig. 4. Detail of the North Entrance area showing the entrance doline and the locations of three slumps and the erosion bowl. The double line is the Timber Ridge Road. Contour intervals are 40 feet $(12$ meters).

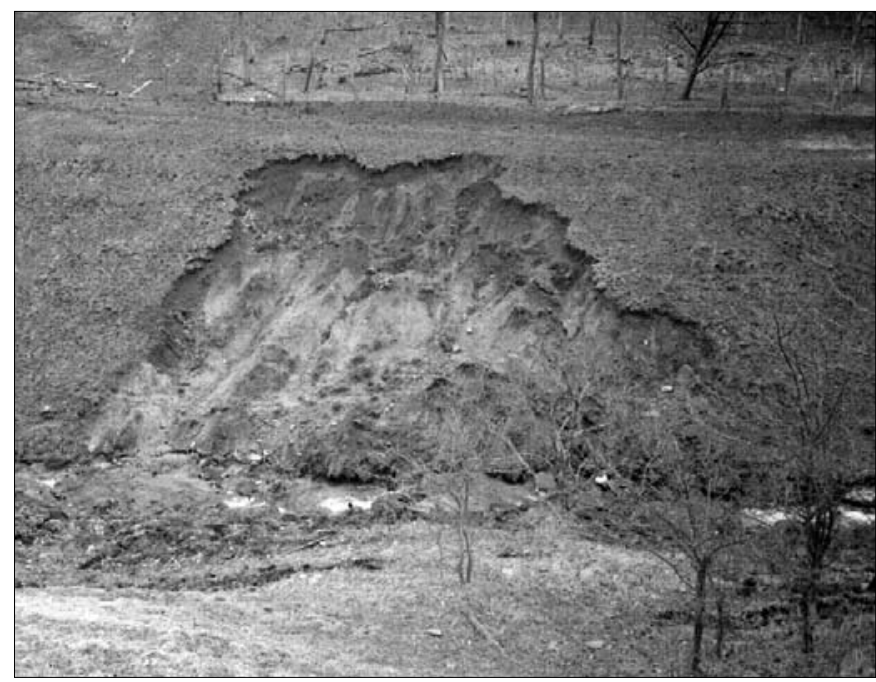

Fig. 5. The medium slump. The material released by bank slumping was injected directly into the North Entrance stream seen flowing at the base of the slump.

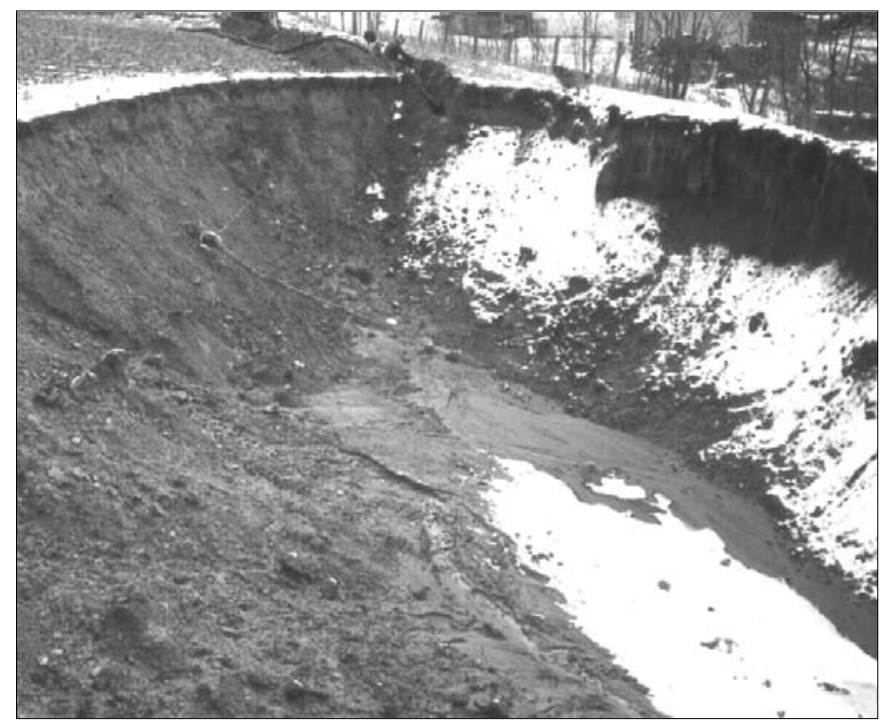

Fig. 6. The erosion bowl viewed upslope.

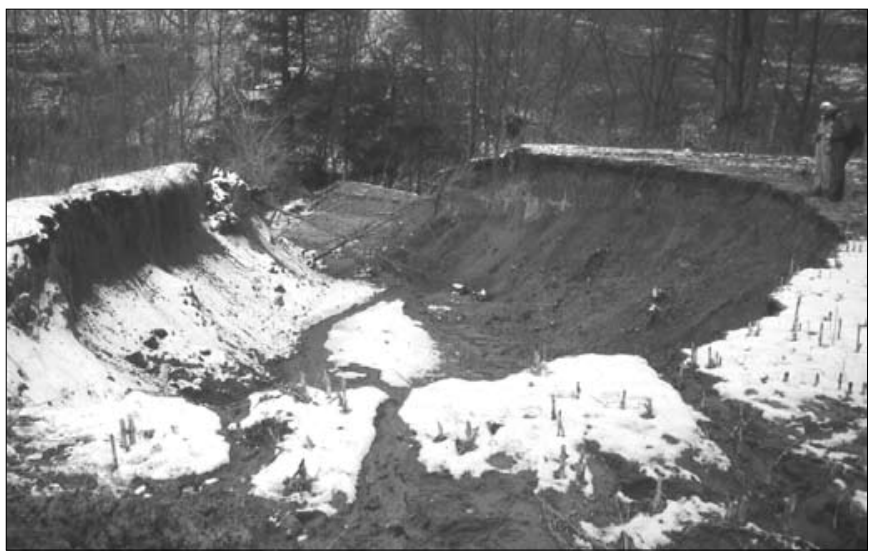

Fig. 7. The erosion bowl viewed downslope. The cave entrance is located behind the trees in the background.

eroded from the erosion bowl contained of a broader range of particle sizes with a significant fraction of cobble-sized colluvium.

One of the authors visited the cave on February 8, 1986 and noted the extreme erosion that had taken place within the entrance doline. At that time, the dimensions of the five major eroded areas were measured as accurately as possible using a 100 foot steel tape and multiple transects. Estimated sediment volumes are:

Erosional bowl

Adjacent slumped area $883 \mathrm{~m}^{3}$

Large slump on wall of depression 306

Medium slump on wall of depression $\quad 272$

Small slump on wall of depression

TOTAL (rounded)

$1800 \mathrm{~m}^{3}$

A surprising observation is that the interior of the cave remained superficially similar in appearance to its pre-flood condition (Fig. 8). However, there was abundant evidence that the portion of the cave downstream from the North Entrance had flooded to the ceiling throughout most of its length. The normal stream bed is on or very close to the bedrock floor of the cave passage. In some instances, lateral terraces of sand to cobble sized alluvium stood as much as 2-3 $\mathrm{m}$ above the stream. Sand deposits of various sizes were found on ledges and on flowstone well above the stream channel (Fig. 9). Cobbles up to $8 \mathrm{~cm}$ in diameter were found wedged into clusters of stalactites $2 \mathrm{~m}$ or more above stream level (Figs. 10, 11). There was some breakage of speleothems, but most of the cave's speleothems were surprisingly intact.

Evidence for recent flooding included tree branches lodged in ceiling cracks, bits of plant materials on ceilings and walls, and numerous fresh deposits of sand, gravel, and cobbles on the floor and sometimes the sidewalls of the cave passage. While the cave contained examples of such deposits prior to the 1985 flood, the presence of fresh plant materials within the apparently new deposits is evidence that the material was deposited in the November flood and not by some older event. Given the $600 \mathrm{~m}$ length and varying width from one to three meters, if the $1800 \mathrm{~m}^{3}$ of sediment had remained in the cave, the floor would have been buried by one or two meters of sediment. Instead the original stream channel was restored with little change in the sediment profile. 


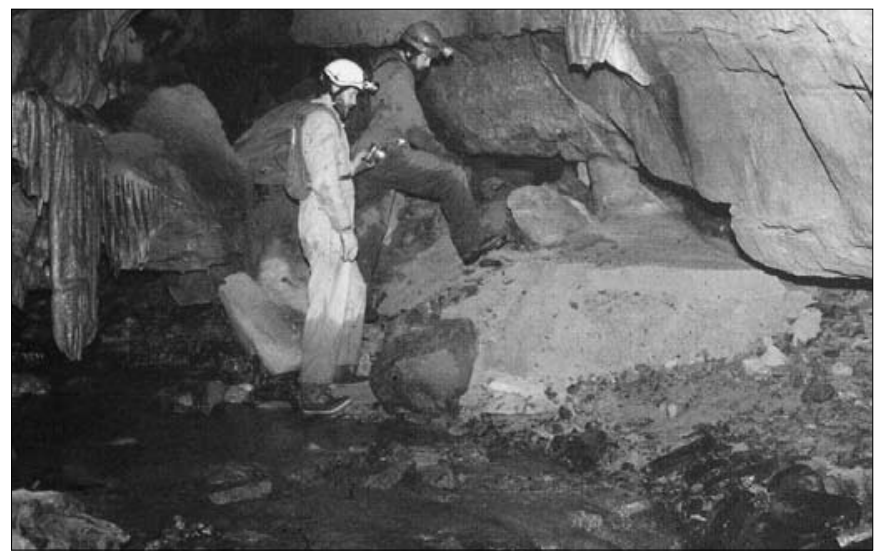

Fig. 8. The post-storm stream channel. The only evidence of massive sediment movement is the sand bar on the bank of the stream.

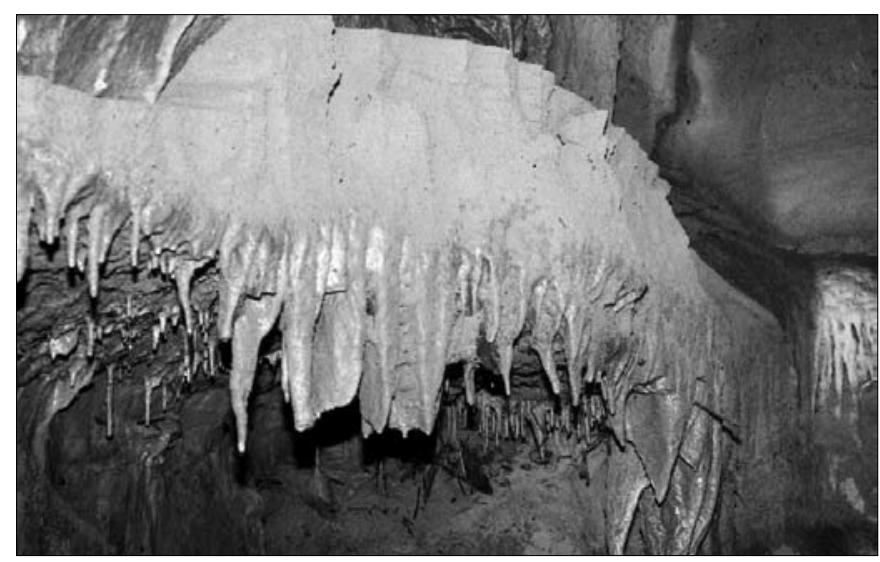

Fig. 9 Sand deposited on a flowstone shelf.

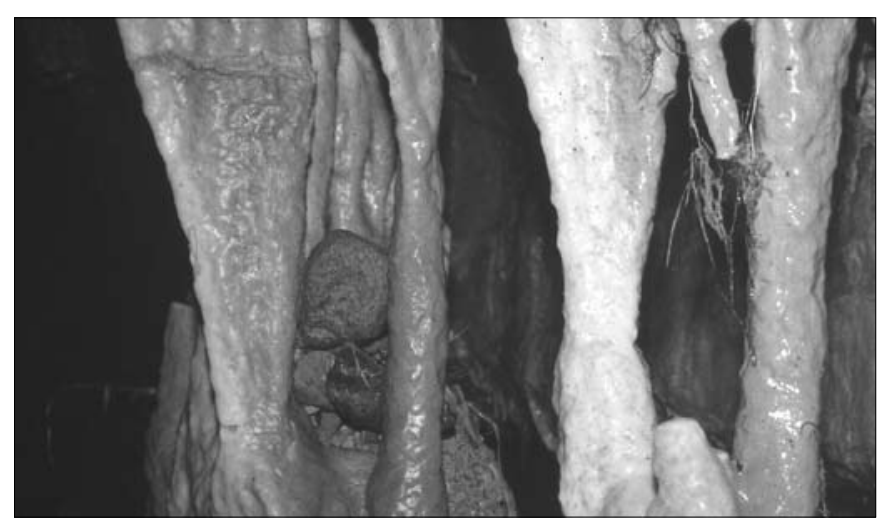

Fig. 10. Stream cobbles wedged into a group of speleothems.

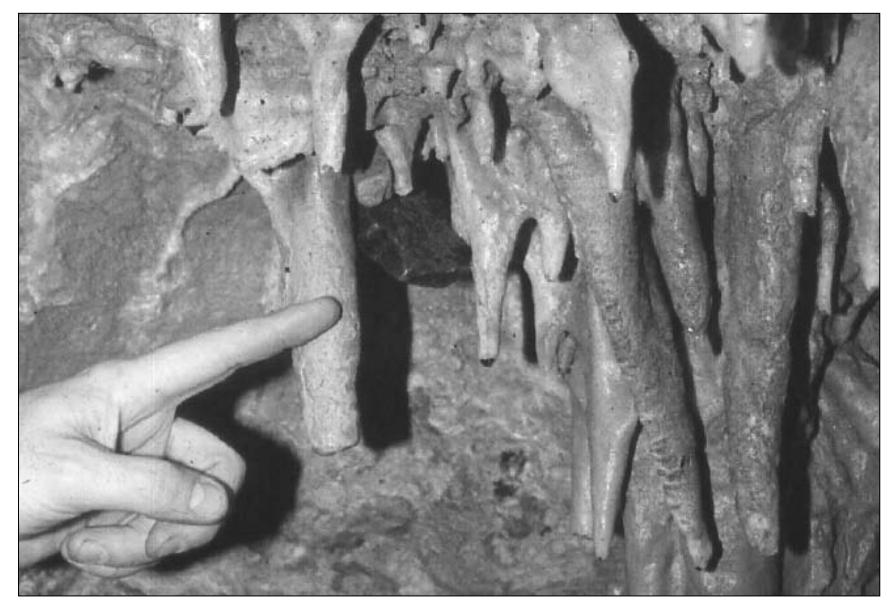

Fig. 11. Stream cobble wedged into a cluster of stalactites on the passage ceiling.

\section{INTERPRETATION OF SEDIMENT TRANSPORT}

The known volume of sediment and the known rainfall intensities allow some estimation of flow and transport within the cave as the sediment mass passed through. The flow in the downstream segment of the cave between the North Entrance and the spring carried all recharge within the catchment including the North Entrance stream, the South Entrance stream, and any other tributaries that might have entered along the channel. There is no surface overflow on this system so the entire recharge into the $180 \mathrm{Ha}$ local watershed passed through the cave. Because soils were saturated from previous storms, nearly all of the November storm appears as overland flow. Depending on which rainfall record is used, the discharge through the cave during the 24 hour period of November 5, 1985 would have been:

Official gauge $267 \mathrm{~mm} 4.8 \times 10^{5} \mathrm{~m}^{3} \quad 5.6 \mathrm{~m}^{3} / \mathrm{s}$ mean discharge

Private gauges $430 \mathrm{~mm} 7.7 \times 10^{5} \mathrm{~m}^{3} 9.0 \mathrm{~m}^{3} / \mathrm{s}$ mean discharge

The mean discharge, of course, is not the peak discharge. The storm hydrograph is unknown but one would expect peak discharges considerably higher than the means along with lower discharges on both limbs of the hydrograph.

Estimating the flow velocity is more speculative. The evidence given above indicates that the downstream segment of the cave was pipe-full during the storm. The property owner states that the entrance doline did not flood significantly during the storm event, nor was there any evidence in February that water had ponded in the doline. The channel bifurcates near the downstream end of the cave with the active stream descending through an inaccessible route to the spring $30 \mathrm{~m}$ lower. The small passage leading from the bifurcation point to the West Entrances acts as a flood overflow route. For a given discharge, velocity varies inversely with passage cross-sectional area. In constricted passages such as the drain to the spring and the West Entrance overflow route with cross-sections of a square meter or less, the mean discharge would have required velocities on the order of $5-9 \mathrm{~m} / \mathrm{s}$. During the peak flow, velocities would have been significantly higher. The upper reaches of the stream passage have larger cross-sections, in the range of $20-30 \mathrm{~m}^{2}$, and would have correspondingly lower velocities. However, the velocity, even in the larger segment of the passage, was sufficient to keep the sediment mass in suspension since little or no material was deposited.

Deposits of unsorted silt, sand, pebbles and cobbles are found as sediment deposits in dry caves. These were described by Bosch \& White (2004) as diamicton facies and are the underground equivalent of landslide deposits found on the surface. Certainly, there were many small slope failures on the steep hillsides near the study site (Jacobson et al., 1987). Diamicton cave deposits were described from New Guinea caves by Gillieson (1986). 
According to the owner, the first visit to the cave in the immediate post-flood period was sometime in December by a group that reported to her that the cave looked essentially the same as it had during their pre-flood visits. This was also the impression of one of the authors during his February visit to the cave. While it was obvious that most of the pre-existing alluvial deposits in the lower stream passage had been reworked during the flood, the total volume of these deposits did not seem to be appreciably greater than it was prior to November of 1985. The numerous existing scraps of lateral terrace deposits and the coarse cobbles jammed into clusters of speleothems along the lower stream passage suggest that the coarse rocky materials derived from the mass wasting and erosion in the entrance doline were transiently deposited in the cave's stream passage when that passage was completely filled with water. Some of these deposits appear to have originally been the several meters in thickness that would have been required if the cave held the entire sediment mass.

The sequence of events for the sediment transport had to have evolved within a period of one or two days when recharge was at its maximum. It is not known if the soil masses broke away simultaneously or sequentially. It is not known if the sediment mass rode the peak of the flood hydrograph or if there were leads or lags. What is known is that some masses of material were apparently deposited and then sheared away as suggested by Figures 8 and 9. By the time the flood had receded, the sediment mass, except for a few pockets, had been flushed through the cave and into Brushy Run.

\section{CONCLUSIONS}

These observations place a considerable constraint on investigations of clastic sediments in dry caves and on the interpretation of sediment dates such as those obtained from cosmogenic isotopes. Entire sediment piles can be deposited by an exceptional flood event and remain stable for long periods of time. More importantly, masses of sediment found on ledges or plastered into recesses of passage walls in dry caves may not all be the same age. The catastrophic character of sediment movement during extreme flood events means that the residual deposits must be interpreted with great care.

\section{ACKNOWLEDGEMENTS}

We are grateful to Ms. Priscilla Teter, the owner of the property, for permitting access to the cave. Cavers Glenn Davis and Richard Marzolf originally called our attention to conditions in the cave. Douglas Van Gundy assisted with the measurements of the slump features. We thank Elizabeth L. White for constructing the cave map.

\section{REFERENCES}

Atteia O. \& Kozel R., 1997 - Particle size distributions in waters from a karstic aquifer: from particles to colloids. Journal of Hydrology, 201: 102-119.
Bosch R.F. \& White W.B., 2004 - Lithofacies and transport of clastic sediments in karst aquifers. In: Sasowsky I.D. \& Mylroie J. (Eds.) - Studies of Cave Sediments. Kluwer Academic, New York: 1-22.

Clark G.M., Jacobson R.B., Kite J.S. \& Linton R.C., 1987 - Storm-induced catastrophic flooding in Virginia and West Virginia, November, 1985. In: Mayer L. \& Nash D. (Eds.) - Catastropic Flooding. Allen \& Unwin, Boston: 355-379.

Dasher G.R., 2001 - The caves and karst of Pendleton County. West Virginia Speleological Survey Bulletin, 15: 247-252.

Davies W.E., 1958 - Caverns of West Virginia. West Virginia Geological and Economic Survey, 19(A): 225227.

Doehring D.O. \& Vierbuchen R.C. - Cave development during a catastrophic storm in the Great Valley of Virginia. Science, 174: 1327-1329.

Dogwiler T. \& Wicks C.M., 2004 - Sediment entrainment and transport in fluviokarst systems. Journal of Hydrology, 295: 163-172.

Drysdale R., Pierotti L., Piccini L. \& Baldacci F., 2001 - Suspended sediments in karst spring waters near Massa (Tuscany), Italy. Environmental Geology, 40: 1037-1050.

Gillieson D., 1986 - Cave sedimentation in the New Guinea Highlands. Earth Surface Processes and Landforms, 11: 533-543.

Herman E.K., Tancredi J., Toran L. \& White W.B., 2007 - Mineralogy of suspended sediment in karst springs in relation to spring water chemistry. Hydrogeology Journal, 15: 255-266.

Herman E.K., Toran L. \& White W.B., 2008 - Threshold events in spring discharge: Evidence from sediment and continuous water level measurement. Journal of Hydrology, 351: 98-106.

Jacobson R.B., Cron E.D. \& McGeehin J.P., 1987 Preliminary results from a study of natural slope failures triggered by the storm of November 3-5, 1985, Germany Valley, West Virginia and Virginia. U.S. Geological Survey Circular, 1008: 11-16.

Mahler B.J. \& Lynch F.L., 1999 - Muddy waters: temporal variation in sediment discharging from a karst spring. Journal of Hydrology, 214: 165-178.

Massei N., Wang H.Q., Dupont J.P., Rodet J. \& Laignel B., 2003 - Assessment of direct transfer and resuspension of particles during turbid floods at a karst spring. Journal of Hydrology, 275: 109-121.

Palmer A.N. \& Palmer M.V., 2005 - Hydraulic processes in the origin of tiankengs. Cave and Karst Science, 32: 101-106.

Teets B. \& Young S., 1985 - Killing Waters. Cheat River Publishing, Terra Alta, West Virginia, $112 \mathrm{p}$.

Tilton J.L., Prouty W.F. \& Price P.H., 1927 - Pendleton County. West Virginia Geological Survey, 384 p. 